\title{
Microbiology
}

Received: September 16, 2014

Accepted after revision: January 19, 2015 Published online: $\mathbf{\square}$

\section{Carriage Rates and Characteristics of Enterobacteriaceae Producing Extended-Spectrum Beta-Lactamases in Healthy Individuals: Comparison of Applicants for Long-Term Care and Individuals Screened for Employment Purposes}

(C) S. Karger AG, Basel PROOF Copy for personal use only ANY DISTRIBUTION OF THIS ARTICLE WITHOUT WRITTEN CONSENT FROM S. KARGER AG, BASEL IS A VIOLATION OF THE COPYRIGHT.

\author{
Fatemeh Ebrahimi $^{\mathrm{a}} \quad$ Julianna Mózes $^{\mathrm{a}} \quad$ Júlia Mészáros $^{\mathrm{b}}$ Ágnes Juhász ${ }^{\mathrm{b}}$ Gábor Kardos ${ }^{\mathrm{a}}$

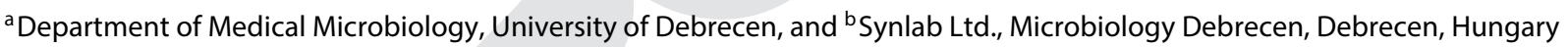

\section{Key Words \\ Colonization $\cdot$ bla $a_{\mathrm{CTX}-\mathrm{M}} \cdot$ Asymptomatic individuals . \\ Escherichia coli $\cdot$ Klebsiella pneumoniae}

\begin{abstract}
Aims: We compared the prevalence of extended-spectrum beta-lactamase (ESBL) producers in the faecal samples of 1,109 healthy individuals screened for employment purposes and in 531 asymptomatic individuals applying for longterm care (LTC). Methods: Eosin-methylene blue agar plates supplemented with $2 \mathrm{mg} / \mathrm{l}$ cefotaxime were used to determine which individuals were ESBL producers. ESBL phenotype was confirmed by double-disk synergy test and ESBL genes were identified by sequencing. ESBL producers were characterized by co-resistance and integron carriage. Results: ESBL producers were more frequent in the LTC applicants than in the employment screening individuals (7.2 vs. $2.0 \% ; \mathrm{p}<0.0001$ ), with 43 Escherichia coli, 18 Klebsiella pneumoniae, 1 Klebsiella oxytoca and 1 Proteus mirabilis being found. In the employment screening individuals, only E. coli was found. Most ESBL genes $(79.4 \%, 50 / 63)$ were bla $a_{\mathrm{CTX}-\mathrm{M}}$ type; bla $a_{\mathrm{CTX}-\mathrm{M}-15}$ was more frequent in the LTC applicants $(\mathrm{p}<$ 0.001). Regarding ESBL genes and integron diversity, E. coli isolates from the LTC applicants were more similar to $K$. pneumoniae than to $E$. coli from the employment screen-
\end{abstract}

ing individuals. Conclusion: These differences in the characteristics of ESBL producers may represent different sources of colonization. Most LTC applicants harboured K. pneumoniae or $E$. coli that were probably hospital-acquired whereas the $E$. coli isolates of many healthy individuals showed similarities to environmental E. coli.

(c) 2015 S. Karger AG, Basel

\section{Introduction}

Enterobacteriaceae that produce extended-spectrum beta-lactamases (ESBLs) have become a major problem worldwide, especially since the occurrence and spread of the $b l a_{\text {СТХ-M }}$ family. Many of these enzymes, in contrast to the $b l a_{\mathrm{TEM}}$ and $b l a_{\mathrm{SHV}}$ groups, are linked to epidemic clones [1] and some of them, e.g. the bla $a_{\mathrm{CTX}-\mathrm{M}-15-\text { produc- }}$ ing Escherichia coli O25b:ST131 and Klebsiella pneumoniae ST11, ST15 and ST147 clonal complexes, have become pandemic both in the nosocomial and community settings as well as in long-term care (LTC) facilities [1-3]. The switch from K. pneumoniae to E. coli as the major ESBL producer species is also linked to the dissemination of $b l a_{\text {CTX-M }}$ genes [4].

The gastrointestinal tracts of humans and even animals are obviously a major source of ESBL producer spe-

\section{KARGER 125}

2015 S. Karger AG, Base

0009-3157/15/0000-0000\$39.50/0

E-Mail karger@karger.com

www.karger.com/che
Gábor Kardos

Department of Medical Microbiology

University of Debrecen, Nagyerdei krt. 98

HU-4032 Debrecen (Hungary)

E-Mail kg@med.unideb.hu 
cies $[5,6]$ and also serve as a site for the horizontal spread of resistance genes [7]. The duration of asymptomatic carriage can be very long, up to several years in some cases [8], and international travel contributes to even more efficient spreading [9]. Carriage rates, and therefore the risk of colonization, in travelers returning home are highest in Southeast Asia [6, 8], as high as 69.3\%. North Africa and the eastern Mediterranean are also associated with a higher carriage risk in travelers [9].

Although a number of studies have been published on faecal carriage rates in different populations (both patients and asymptomatic individuals), colonization patterns have only started to be understood. Therefore, the aim of this study was to compare the prevalence of faecal carriage and the characteristics of ESBL producers among applicants for LTC and individuals screened for employment purposes.

\section{Materials and Methods}

\section{Samples and Isolates}

A total of 1,640 faecal samples from 2 groups of asymptomatic individuals not suffering from infection at the time of sampling were investigated between March 2009 and April 2010. Samples were collected and sent for screening for enteric pathogens from 1,109 individuals ( 300 males and 809 females with a median age of 34 years, range 15-68 years) being screened for employment eligibility purposes (e.g. jobs at hospitals, kindergartens and food-processing plants) and 531 individuals (218 males and 313 females with a median age of 75 years, range $0-100$ years) who needed to be screened prior to admittance to LTC facilities. The vast majority of individuals were located in north-eastern Hungary from the EU regions of Northern Hungary and the Northern Great Plain.

The samples were directly inoculated onto eosin-methylene blue agar plates supplemented with $2 \mathrm{mg} / \mathrm{l}$ cefotaxime. All colonies with different morphology were further identified by means of biochemical tests; enterobacterial isolates were then processed further.

According to Clinical and Laboratory Standards Institute guidelines, antibiotic susceptibility testing was performed by the disc-diffusion method against imipenem, cefotaxime, ceftazidime, cefepime, ciprofloxacin, colistin, trimethoprim-sulfamethoxazole (co-trimoxazole), doxycycline, amikacin, gentamicin, tobramycin and tigecycline. All isolates showing a decreased susceptibility to at least 1 third-generation cephalosporin or to cefepime were tested for ESBL phenotype using the double-disc synergy test (Oxoid, Basingstoke, UK) and then re-identified using a MALDI Biotyper (Bruker, Bremen, Germany). Imipenem-resistant isolates were also tested using the Hodge test as specified in the Clinical and Laboratory Standards Institute guidelines.

In the case of isolates displaying an ESBL phenotype, DNA was extracted by heat treatment. PCR amplifications were carried out in a MyCycler PCR machine (BioRad, Hercules, Calif., USA). Species identification for K. pneumoniae and E. coli isolates was confirmed by species-specific PCRs [10,11].

\section{Genetic Relatedness}

The epidemiological relationship was analyzed by enterobacterial repetitive intergenic consensus PCR (ERIC-PCR) with ERIC2 and ERIC1R primers (as described earlier [12]) and pulsed-field gel electrophoresis (PFGE). Plugs were prepared as described earlier [13], macrorestriction was performed using XbaI (Fermentas, Vilnius, Lithuania) in a CHEF DRIII machine (Bio-Rad) in $1 \%$ SeaKem Gold agarose (Lonza) at $14^{\circ} \mathrm{C}$. Electrophoresis was performed at $6 \mathrm{~V} / \mathrm{cm}$, with a reorientation angle of $120^{\circ}$, and switch times were ramped between 2 and $64 \mathrm{~s}$ for $20 \mathrm{~h}$ for both species. Gels were stained with ethidium bromide and visualized under UV light. Banding patterns were analyzed with Fingerprinting II software (Bio-Rad). The threshold for probable unrelatedness was set at $<85 \%$ similarity. The Simpson index of diversity (D) was calculated to assess diversity, as described earlier [14].

\section{Identification of ESBL Genes}

The $b l a_{\mathrm{TEM}}, b l a_{\mathrm{SHV}}, b l a_{\mathrm{CTX}-\mathrm{M}}$ genes were detected by PCR, as described previously [15-17]; $b l a_{\mathrm{TEM}}$ and $b l a_{\mathrm{SHV}}$ genes were identified by sequencing (Macrogen, Amsterdam, The Netherlands) using the same primers, while $b l a_{\text {СTХ-M }}$ genes were identified by the sequencing of primers of group-specific PCRs [18]. Sequence alignment and analyses were performed using CLC DNA Workbench v4.0 (CLC Bio, Aarhus, Denmark).

\section{Aminoglycoside Resistance Genes and Characterization of Integrons}

The aminoglycoside resistance genes aac(3')-IIa (aacC2), $\operatorname{aac}\left(6^{\prime}\right)-I b(a a c A 4), \operatorname{aph}\left(3^{\prime}\right)-I a(a p h A 1), \operatorname{ant}\left(2^{\prime}\right)-I a(a a d B), \operatorname{ant}\left(3^{\prime}\right)$ Ia (aadA1), armA, rmtA and $r m t B$ were sought for as previously described [19-22]. The detection of class 1 and class 2 integrons was performed by PCR assays according to Mazel et al. [23] and the amplification and sequencing of the variable regions were performed as described by White et al. [24], using newly designed internal primers when necessary. Sequences were assembled in the CLC DNA Workbench 4.0 (CLC Bio), and gene cassettes were identified using the GenBank (http://www.ncbi.nlm.nih.gov). Identification of class 1 and class 2 integrons with variable regions of the same size was performed by restriction analysis using at least two enzymes for each cassette array, including EcoRI, HindIII, MseI and RsaI (Fermentas).

\section{Phylogenetic Analysis of E. coli and Virulence Genes}

Phylogenetic groups of $E$. coli were determined using the multiplex PCR method developed by Clermont et al. [25]. Phylogroups $\mathrm{A}$ and $\mathrm{B} 1$ are considered commensal, while groups $\mathrm{B} 2$ and $\mathrm{D}$ include strains responsible for extra-intestinal infections [25]. The pandemic O25b-ST131 clone was screened in the isolates of the phylogenetic group B2 with a PCR-based assay [26].

A multiplex PCR assay was used to determine the presence of virulence factor genes characteristic for enterovirulent $E$. coli pathotypes, as described previously [27].

We used PCR with previously described primers to search for genes coding for the putative extra-intestinal virulence factors of E. coli, including adhesins ( $p a p C$, fimH, sfaS and $s f a / f o c D E$ ), toxins ( $c n f 1$ and $c v a C$ ), factors related to iron acquisition (iutA and $f y u A$ ), the capsule system ( $k p s M T I I)$ and miscellaneous factors ( $i b e A$, PAI, traT and $\operatorname{csg} A$ ) [28]. 


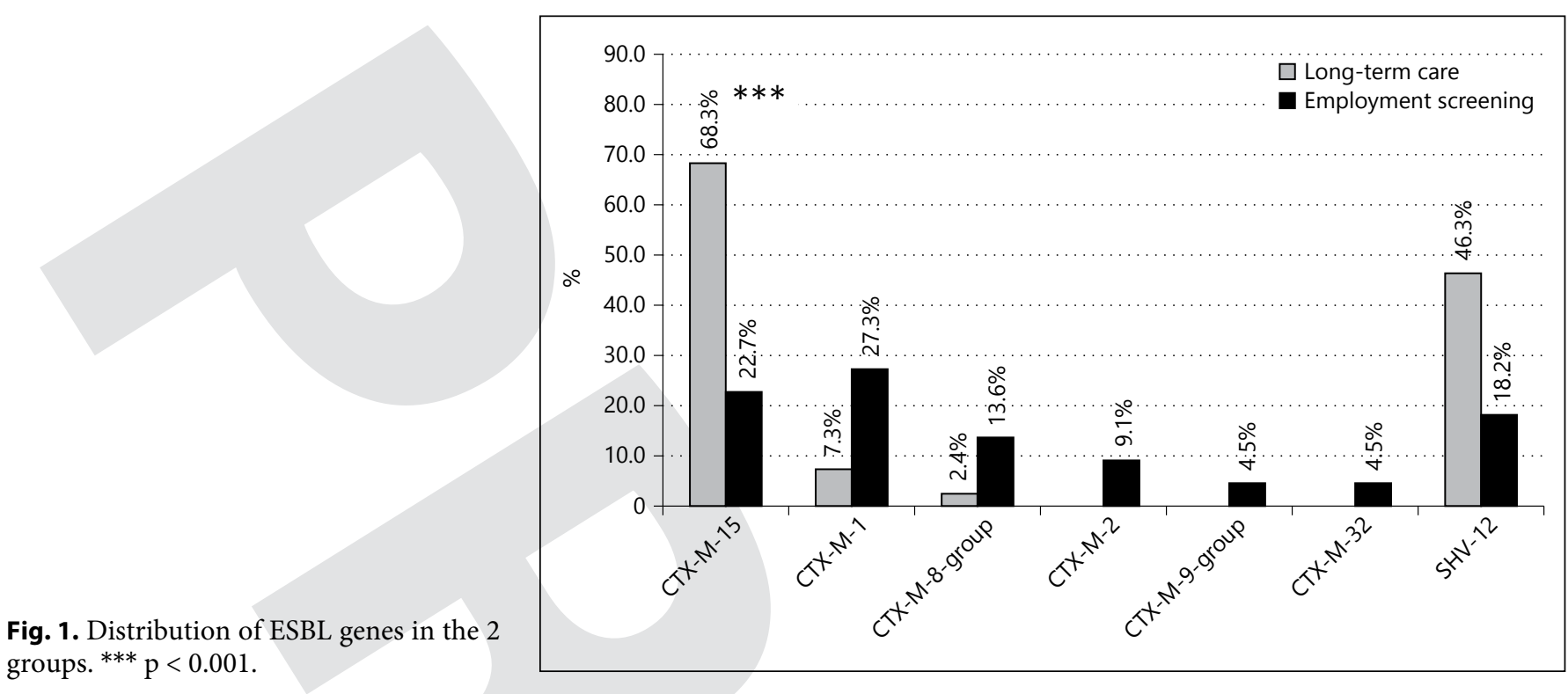

Fig. 1. Distribut groups. ${ }^{* * *} \mathrm{p}<0.001$.

\section{Statistical Analysis}

Prevalences were compared by means of the $\chi^{2}$ test or the Fisher exact test as appropriate. Age distribution in the different groups was compared by means of the Kolmogorov-Smirnov test. The distribution of genes coding for ESBLs, aminoglycosidemodifying enzyme genes and co-resistance patterns were all analyzed by $\chi^{2}$ test, and the pairwise comparisons derived were adjusted with the Bonferroni correction. The association of genes with each other or with different characteristics was analyzed using the Pearson correlation. PAST v3.0 was used to perform the statistical tests [29].

\section{Results}

\section{Epidemiology of ESBL Producers}

The overall prevalence of ESBL carriers was 3.7\% $(60 / 1,640)$. The LTC facility applicants carried ESBL producers $(7.2 \%$; 38/531) significantly more frequently $(\mathrm{p}<$ 0.001 ) than the individuals on employment screening $(2.0 \% ; 22 / 1,109)$. The risk of carriage of ESBL producers was not affected by the region where patients lived, by their gender or by their age in any of the comparisons.

Of the 63 ESBL-producing isolates from the $60 \mathrm{pa}-$ tients, 43 E. coli, 18 K. pneumoniae, 1 Klebsiella oxytoca and 1 Proteus mirabilis were identified. Three individuals harboured multiple ESBL-producing isolates simultaneously (K. pneumoniae and E. coli in 2 individuals and $K$. oxytoca and E. coli in 1 individual, all from the LTC applicant group). Among the individuals on employment screening, only $E$. coli isolates could be found, but the proportion of E. coli and K. pneumoniae isolates was similar (21/41 vs. 18/41) in the LTC facility applicants.

Out of the 63 ESBL-positive isolates, 50 harboured a $b l a_{\text {CTX-M }}$ gene; the majority of these were E. coli $(38 / 50)$. The distribution of ESBL genes in the 2 groups is shown in figure 1 . All isolates carrying $b l a_{\text {СTX-M }}$ other than bla $a_{\text {CTX-M-15 }}$ were E. coli; $1 \mathrm{E}$. coli isolate harboured $b l a_{\text {CTX-M-15 }}$ and bla $a_{\text {CTX-M-2 }}$ simultaneously. All K. pneumoniae and $5 \mathrm{E}$. coli isolates (11.6\%) carried bla $a_{\mathrm{SHV}-12}$; in the case of $K$. pneumoniae, 11 isolates harboured $b l a_{\mathrm{CTX}-\mathrm{M}-15}$ and $b l a_{\mathrm{SHV}-12}$ at the same time. The distribution of the ESBL genes was significantly different $(\mathrm{p}=$ 0.001 ) between the 2 study groups; $b l a_{\mathrm{CTX}-\mathrm{M}-15}$ was more frequent in the LTC applicants ( $\mathrm{p}<0.001)$, and the frequencies of other genes were comparable. When comparing ESBL gene distribution among $K$. pneumoniae (all from the LTC applicants), E. coli from the LTC applicants and $E$. coli from the people on employment screening, a significant difference was found $(\mathrm{p}<0.001)$. All 3 isolate groups showed significantly different distributions in pairwise comparisons $(\mathrm{p}<0.001$ to $\mathrm{p}=0.026$ ), mostly due to the different distribution of $b l a_{\mathrm{CTX}-\mathrm{M}-15}$. In addition, $K$. pneumoniae carried $b l a_{\mathrm{SHV}-12}$ more frequently than E. coli among the LTC applicants and in the employment screening group ( $\mathrm{p}<0.001)$.

\section{Genetic Diversity}

The genetic diversity among $E$. coli isolates was high on both ERIC-PCR (data not shown) and PFGE (fig. 2; $\mathrm{D}=0.99$ and 0.96 , respectively). One isolate was not 


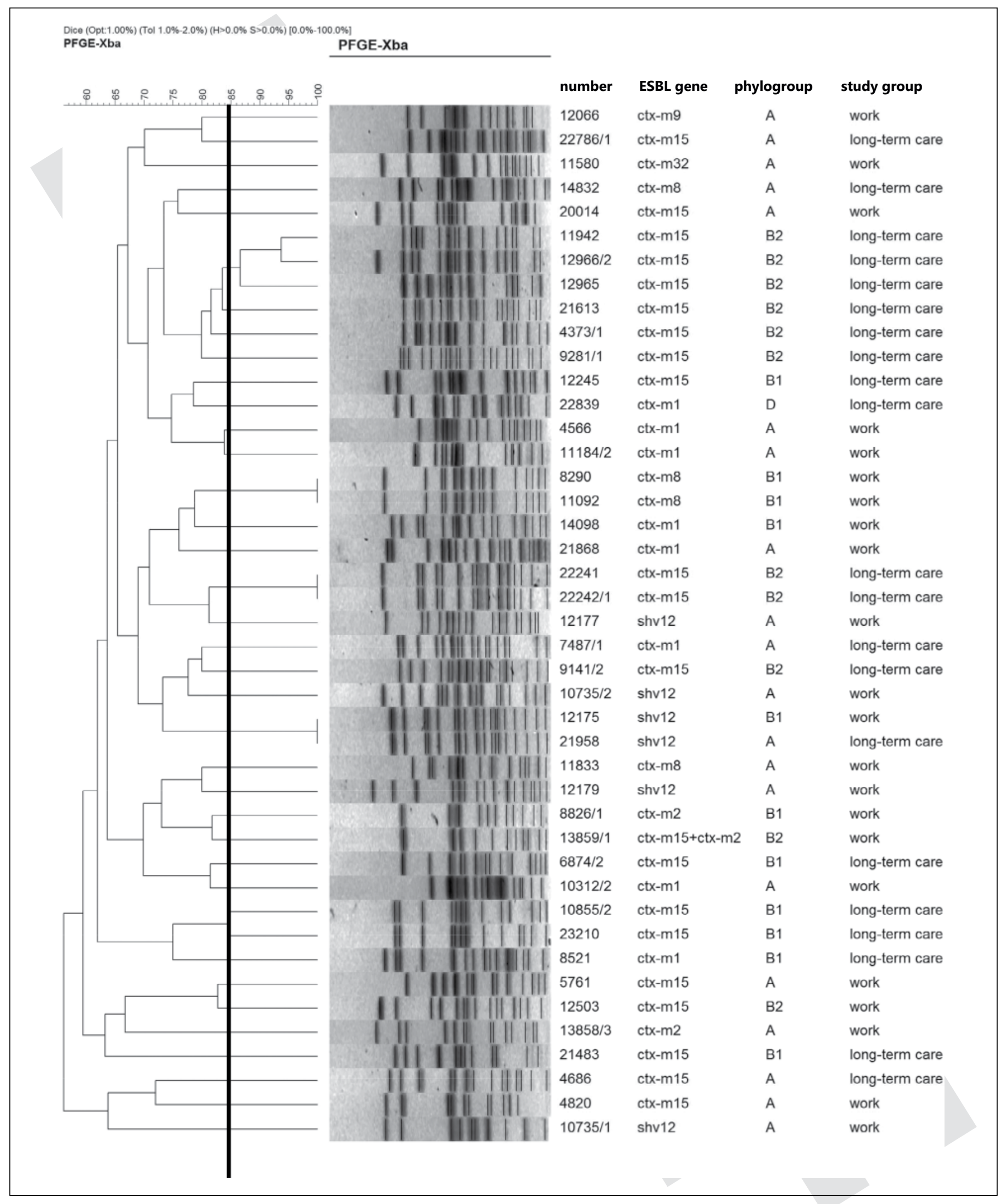

Fig. 2. Dendrogram generated from macrorestriction patterns of the E. coli isolates. 


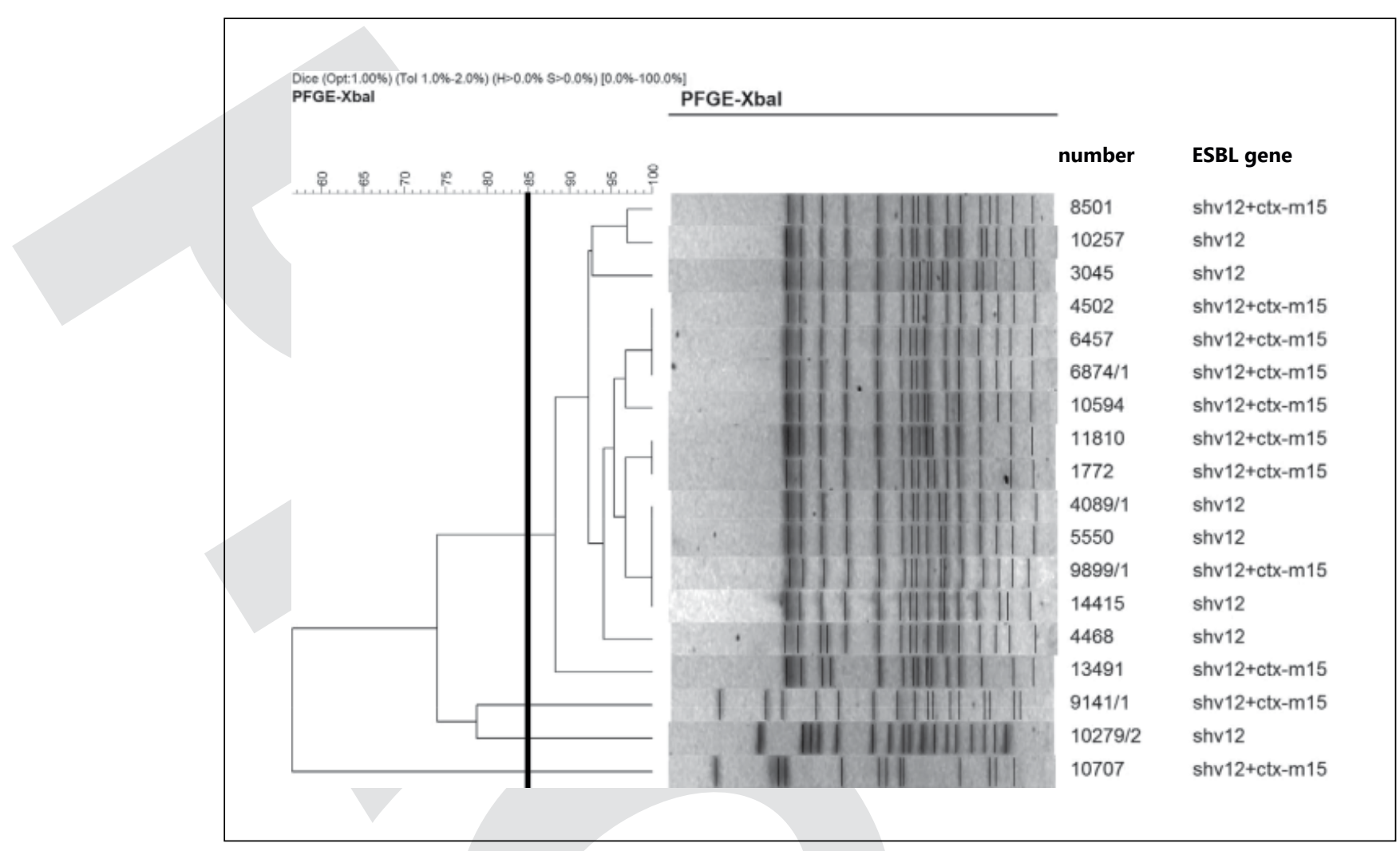

Fig. 3. Dendrogram generated from macrorestriction patterns of K. pneumoniae isolates.

typeable with ERIC-PCR but its PFGE analysis was successful. The diversity of $E$. coli between the 2 groups was comparable $(\mathrm{D}=0.99$ vs. 0.99 and $\mathrm{D}=0.94$ vs. 0.95 , respectively). Isolates in the same cluster were not uniform with regard to the ESBL genes and integrons carried.

In contrast, $K$. pneumoniae isolates were markedly less diverse, both with ERIC-PCR (data not shown) and PFGE (fig. 3 ; $\mathrm{D}=0.58$ and 0.31 , respectively); a PFGE clone containing 15 of the 18 isolates was detected. Notably, 1 of the distinct isolates was the carbapenem nonsusceptible isolate.

\section{Resistance Patterns and Aminoglycoside Resistance Genes}

All ESBL-producing isolates were susceptible to colistin; carbapenem nonsusceptibility (Hodge test: negative) was detected in a single K. pneumoniae isolate harbouring bla $a_{\mathrm{SHV}-12}$. The K. pneumoniae clone detected was resistant to all the drugs tested, except for carbapenem and colistin, and it carried the aac (6')-Ib gene but no other tested aminoglycoside resistance genes.
As shown in figure 4, resistance rates significantly differed between $E$. coli isolates from individuals on employment screening and on screening for LTC admission in the case of ciprofloxacin, amikacin, tobramycin and trimethoprim-sulfamethoxazole $(\mathrm{p}=0.048$ to $\mathrm{p}<0.002)$. When comparing commensal vs. pathogenic E. coli isolates as classified by phylogroups, the resistance pattern was similar; however, the significant differences in ciprofloxacin and trimethoprim-sulfamethoxazole disappeared. In contrast to the K. pneumoniae clone, isolates showing resistance to all non-beta-lactam antibiotic groups (except colistin) were not found in either E. coli group.

In the E. coli isolates, the presence of the bla $a_{\mathrm{CTX}-\mathrm{M}-15}$ gene correlated positively with ciprofloxacin, amikacin and tobramycin resistance (table 1 ). The gene $b l a_{\mathrm{CTX}-\mathrm{M}-1}$, on the contrary, correlated negatively with resistance to amikacin and tobramycin.

The prevalences of aminoglycoside resistance genes are shown in figure 5; all isolates were negative for ant (2')$I a, a r m A, r m t A$ and $r m t B$ genes. In the case of $E$. coli from the LTC applicants, aminoglycoside resistance genes were distributed unevenly $(p=0.017)$ with more frequent 


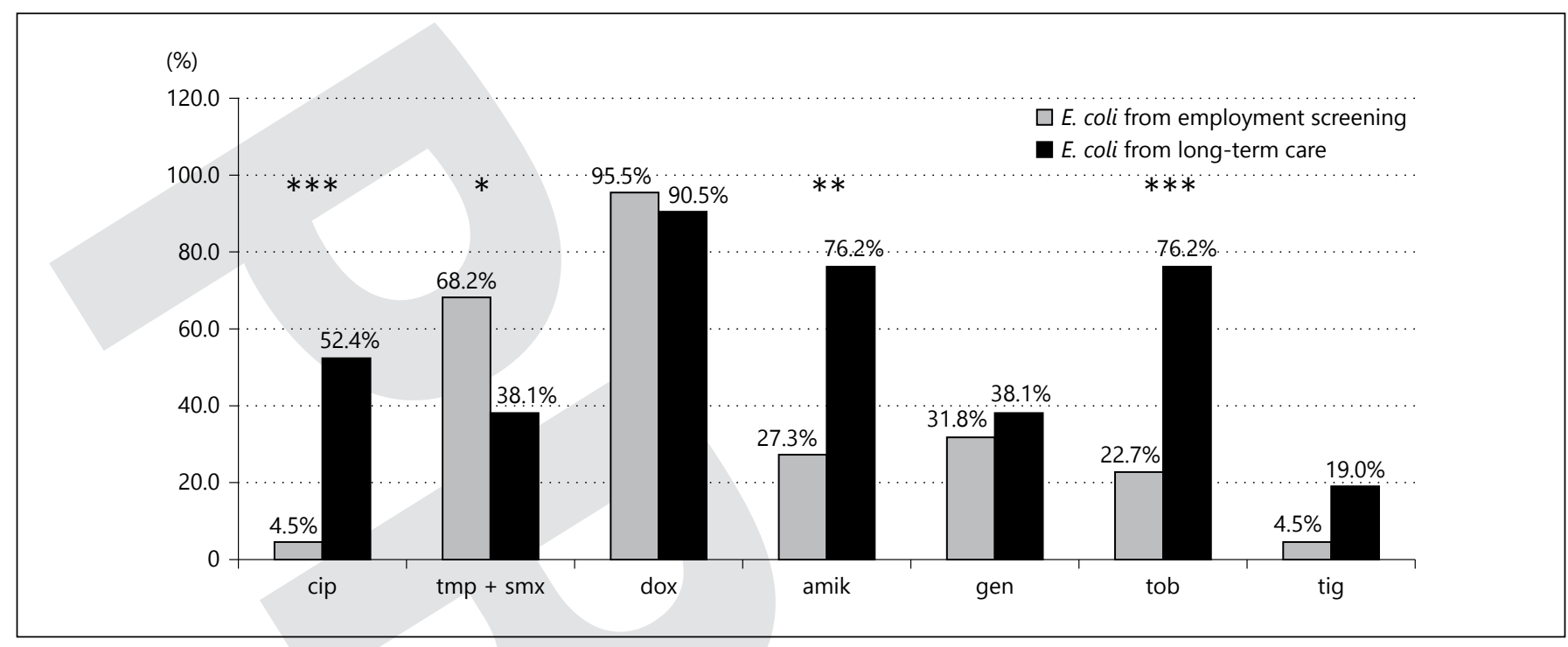

Fig. 4. Resistance rates in ESBL-producing isolates obtained from long-term care facility applicants and individuals on employment screening. amik = Amikacin; cip = ciprofloxacin; dox $=$ doxycy- cline; gen = gentamicin; tig = tigecycline; tmp + smx = trimethoprim-sulfamethoxazole (co-trimoxazole); tob = tobramycin. ${ }^{*} \mathrm{p}<0.05$; $^{* *} \mathrm{p}<0.01$; $^{* * *} \mathrm{p}<0.001$.
Table 1. Correlation of carriage of bla $a_{\mathrm{CTX}-\mathrm{M}-15}$ and $b l a_{\mathrm{CTX}-\mathrm{M}-1}$ with resistance to antibiotics and aminoglycoside resistance genes in E. coli isolates

\begin{tabular}{|c|c|c|}
\hline & $b l a_{\mathrm{CTX}-\mathrm{M}-15}$ & $b l a_{\mathrm{CTX}-\mathrm{M}-1}$ \\
\hline Ciprofloxacin resistance & $\mathrm{r}=0.43^{* *}$ & n.s. \\
\hline Gentamicin resistance & n.s. & n.s. \\
\hline Amikacin resistance & $\mathrm{r}=0.58^{* * *}$ & $\mathrm{r}=-0.41^{* *}$ \\
\hline Tobramycin resistance & $\mathrm{r}=0.63^{* * *}$ & $\mathbf{f}=-0.39^{* *}$ \\
\hline Tigecycline resistance & n.s. & n.s. \\
\hline Carriage of $\operatorname{aac}\left(3^{\prime}\right)-I I a$ & $\mathrm{r}=0.39^{*}$ & n.s. \\
\hline Carriage of $a a c\left(6^{\prime}\right)-I b$ & $\mathrm{r}=0.70^{* * *}$ & $\mathrm{r}=-0.40^{*}$ \\
\hline Carriage of $a p h\left(3^{\prime}\right)-I a$ & $\mathbf{r}=-0.35^{*}$ & n.s. \\
\hline Carriage of ant(3")-Ia & $\mathbf{r}=-0.36^{*}$ & n.s. \\
\hline Carriage of class I integron & $\mathbf{r}=-0.49^{* * *}$ & n.s. \\
\hline
\end{tabular}

n.s. $=$ Not significant. Bold text represents negative correlations. ${ }^{*} \mathrm{p}<0.05$; $^{* *} \mathrm{p}<0.01{ }^{* * *} \mathrm{p}<0.001$.

carriage of $a a c\left(6^{\prime}\right)-I b$ than $a p h\left(3^{\prime}\right)-I a$ and ant (3')-Ia ( $\mathrm{p}=$ 0.048 for both comparisons), but not more frequent than the carriage of $\operatorname{aac}\left(3^{\prime}\right)-I I a$. In the E. coli from the employment screening group, the gene distribution was also uneven ( $\mathrm{p}<0.001)$, but ant $\left(3^{\prime}\right)$-Ia was more dominant than $a a c\left(6^{\prime}\right)-I b$ and $a p h\left(3^{\prime}\right)-I a(\mathrm{p}=0.005$ and $\mathrm{p}=0.02$, respectively). When applying the phylogroup-based classification of $E$. coli, pathogenic isolates showed a pattern very similar to that of the isolates from the LTC applicants, but the dominance of $a a c\left(6^{\prime}\right)-I b$ over $a p h\left(3^{\prime}\right)-I a$ and $a n t\left(3^{\prime}\right)$ $I a$ was more marked ( $\mathrm{p}=0.004$ for both comparisons). The commensal isolates were similar to the isolates from the employment screening group.

The presence of the $b l a_{\mathrm{CTX}-\mathrm{M}-15}$ gene in $E$. coli was associated with the presence of $a a c\left(3^{\prime}\right)-I I a$ as well as $a a c\left(6^{\prime}\right)$ $I b$, and it correlated with the absence of $a p h\left(3^{\prime}\right)-I a$ and ant(3')-Ia (table 1). The carriage of bla $a_{\mathrm{CTX}-\mathrm{M}-1}$, in turn, was negatively correlated with $a a c\left(6^{\prime}\right)-I b$.

\section{Integrons}

The K. pneumoniae clone carried a class 1 integron with a single ant ( $\left.3^{\prime}\right)-1 b$ gene, which was also found in 2 of the 3 independent isolates. In E. coli, integron carriage correlated negatively with bla $_{\text {CTX-M-15 }}$ (table 1 ). The carriage rate of class 1 integrons was significantly higher in the $E$. coli from the employment screening group than from the LTC applicants $(68.2 \%, 15 / 22$ vs. $28.6 \%, 6 / 21$; $\mathrm{p}=0.01)$. Class 2 integrons were found in $6.3 \%(4 / 63)$ of the isolates ( 3 among the LTC facility applicants and 1 in an individual for employment screening); of these, 2 E. coli isolates harboured both integron types (1 isolate was from the LTC applicant group and the other from the employment screening group).

Seven and 2 different gene cassette arrays were identified amongst the class 1 and 2 integrons, respectively (fig. 6). These arrays did not show any association with the ESBL gene carried or the study group of origin. 


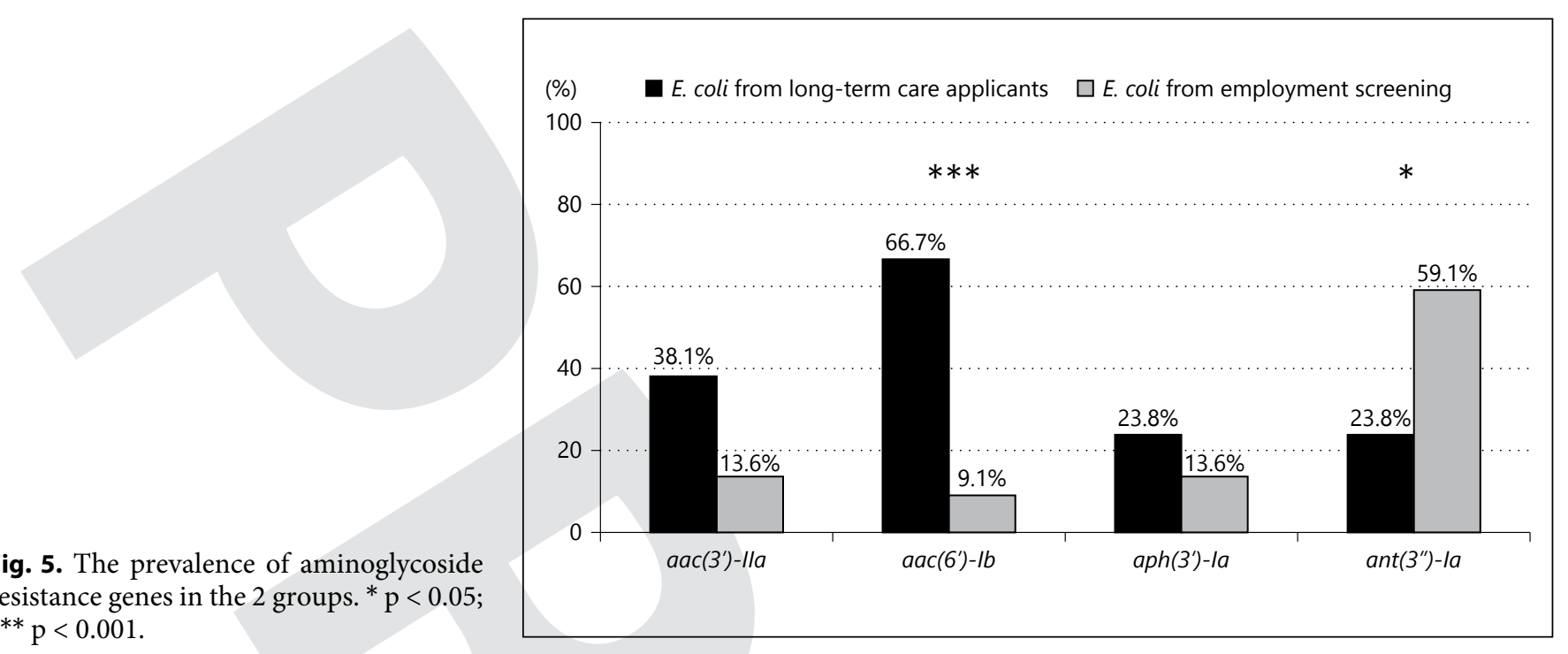

Fig. 5. The prevalence of aminoglycoside resistance genes in the 2 groups. ${ }^{*} \mathrm{p}<0.05$ $* * * \mathrm{p}<0.001$

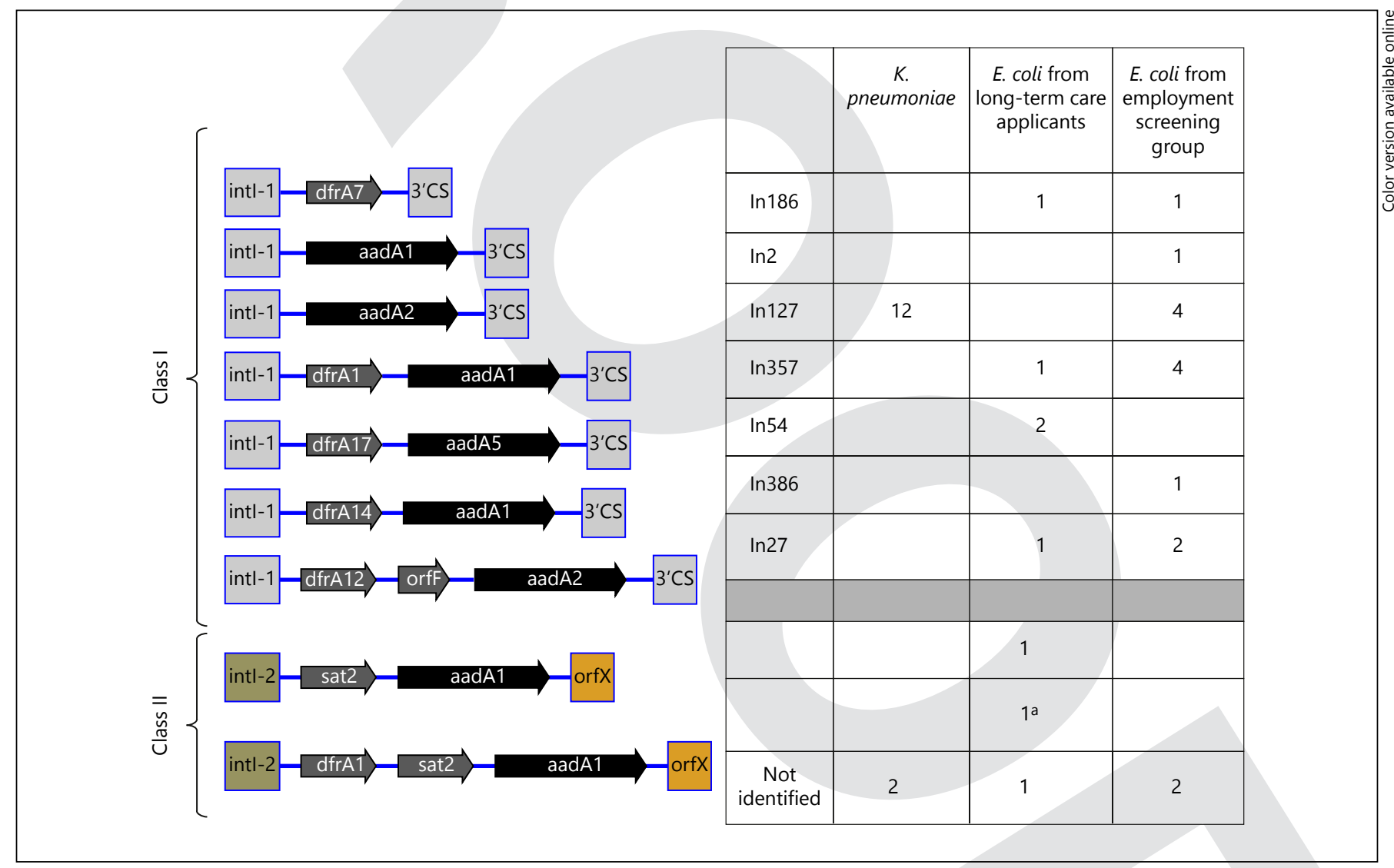

Fig. 6. Schematic representation of the various cassette arrangements found in class 1 and class 2 integrons. The arrows display different genes. The grey boxes indicate the $3^{\prime}$ and $5^{\prime}$ conservative segments. Integron numbers for class 1 integrons according to the
Integrall database (http://integrall.bio.ua.pt/?nomenclature) are also shown. The number of isolates carrying each cassette array is shown on the right. ${ }^{\text {a }}$ The $P$. mirabilis isolate also carried this array. 
Table 2. Distribution of virulence genes according to E. coli phylogenetic groups

\begin{tabular}{llllll}
\hline \multirow{2}{*}{ Gene } & \multicolumn{5}{c}{ Number of positive isolates per phylogroup } \\
\cline { 2 - 6 } & $\mathrm{A}$ & $\mathrm{B} 1$ & $\mathrm{~B} 2$ & $\mathrm{D}$ & \multicolumn{1}{l}{ Total } \\
$(\mathrm{n}=20)$ & $(\mathrm{n}=10)$ & $(\mathrm{n}=11)$ & $(\mathrm{n}=2)$ & $(\mathrm{n}=43)$ \\
\hline iutA & 6 & 6 & 8 & 1 & $21(48.8 \%)$ \\
papC & 1 & 2 & 3 & 1 & $7(16.3 \%)$ \\
kpsMT II & 5 & 1 & 8 & 1 & $15(34.9 \%)$ \\
fyuA & 3 & 4 & 10 & 1 & $18(41.9 \%)$ \\
sfaS & 0 & 0 & 3 & 0 & $3(7.0 \%)$ \\
cvaC & 5 & 6 & 4 & 0 & $15(34.9 \%)$ \\
traT & 9 & 10 & 9 & 1 & $29(67.4 \%)$ \\
cnf1 & 0 & 0 & 2 & 0 & $2(4.6 \%)$ \\
ibeA & 0 & 0 & 3 & 0 & $3(7.0 \%)$ \\
sfa/focDE & 0 & 0 & 3 & 0 & $3(7.0 \%)$ \\
PAI & 0 & 0 & 10 & 1 & $11(25.6 \%)$ \\
fimH & 15 & 10 & 11 & 2 & $38(88.4 \%)$ \\
csgA & 19 & 10 & 2 & 1 & $32(74.4 \%)$ \\
\hline
\end{tabular}

\section{Phylogrouping of E. coli and Analysis of Virulence}

Genes

Phylogenetic group analysis showed that group A covered $46.5 \%$ of strains, followed by groups B2 (25.6\%), B1 (23.3\%) and D (4.6\%). The commensal E. coli phylogroup A was more frequent in the employment screening group (14/22 vs. $6 / 21 ; p=0.02)$, but phylogroup B2 was more frequent in the LTC applicants (9/21 vs. $2 / 22 ; \mathrm{p}=0.01)$. All phylogroup B2 isolates belonged to the $b l a_{\mathrm{CTX}-\mathrm{M}-15}$ producer O25b:ST131 pandemic clone.

None of the isolates belonged to the entero-virulent pathogroups for which tests were conducted. The frequency of the examined extra-intestinal virulence factor according to phylogroup is shown in table 2 . Isolates belonging to pathogenic phylogroups showed a higher prevalence of the genes kpsMT II $(\mathrm{p}=0.002)$ and fyuA $(\mathrm{p}<0.001)$ than those from commensal phylogroups. The genes $s f a S, c n f 1$, ibeA, sfa/focDE and PAI were completely absent from the commensal isolates. The comparison E. coli isolates according to source population yielded similar results, but only the prevalence of PAI was significantly different $(p=0.017)$. Virulence factor patterns were not linked to the type of ESBL gene carried.

\section{Discussion}

Asymptomatic carriage of ESBL-producing Enterobacteriaceae was documented as early as 1989 in hospital patients [30], and reports of carriage in healthy individu- als soon followed $[31,32]$. It became obvious that different geographical regions show different carriage rates in communities, ranging from 0.6 to $11.6 \%$ in Europe [6], with the highest prevalence being reported in LTC applicants from Belgium. Much higher rates have been found in other regions, e.g. 63.3\% in Egypt [33] and 69.3\% in Thailand [34]. This geographical difference is underlined by studies reporting international travel as a risk factor for the carriage of ESBL producers $[8,35,36]$. Faecal carriage rates seem to be increasing $[6,37,38]$.

The prevalence rate found in this study among healthy individuals (those screened for employment purposes) is comparable or somewhat lower than rates reported by European studies $[39,40]$. In contrast, the LTC applicants showed much higher prevalence, closer to that seen in hospitalized patients who were free of ESBL-related infections [41] a few years earlier and also that found in a contemporary study from Belgium targeting a similar patient group [42].

The distribution of the ESBL genes in the 2 study populations differed. In the K. pneumoniae and E. coli from the LTC applicants, it was similar to that in a European study on ESBL producers from human clinical samples [43], while higher gene diversity was found in the E. coli from the employment screening group.

Co-resistance patterns showed similarities with previous findings, e.g. the association of $b l a_{\text {СТХ-M }}$ genes with ciprofloxacin and amikacin resistance $[44,45]$. Co-resistance, as expected, was highest in K. pneumoniae [45], with a single, multi-resistant clone being dominant among the isolates. The co-resistance pattern of the 2 E. coli types was also very different. Resistance to ciprofloxacin, amikacin and tobramycin was significantly more prevalent in the LTC applicants, with the amikacin and tobramycin resistance being caused mainly by carriage of the $a a c\left(6^{\prime}\right)-I b$ gene linked to $b l a_{\mathrm{CTX}-\mathrm{M}-15}$ carriage. In agreement, it was also shown that ciprofloxacin resistance is associated with aminoglycoside resistance in ESBL-producer and non-ESBL producer E. coli [46].

In contrast, ESBL producers from the employment screening individuals were characterized by lower co-resistance rates, a low frequency of $a a c\left(6^{\prime}\right)-I b$ and a high prevalence of ant (3')-Ia, a gene which is frequently present in the intestinal E. coli of healthy individuals [47]. This difference can be attributed to the high frequency of the ST131 carrying $b l a_{\mathrm{CTX}-\mathrm{M}-15}$ in the LTC applicant group, while $b l a_{\text {СтХ-М-1 }}$ carrier isolates, regardless of origin, were characterized by their low rate of co-resistance to other antibiotic classes and their lack of the $a a c\left(6^{\prime}\right)-I b$ gene. In addition, several virulence factors were more frequently 
found in the isolates from LTC applicants, also attributable to the higher frequency of ST131 in this group.

The differences in the distribution of the carried ESBL genes and other characteristics between the 2 populations in this study may be explained, in our opinion, by the different probable source of colonization. Most carriers in the group being screened for work eligibility presumably represent acquisition events independent of hospitals (rather community-related) whereas the group of LTC applicants probably represents mainly nosocomial acquisition. This serves as an explanation for the observations that K. pneumoniae, a typical nosocomial pathogen, was absent in the employment screening group, and that the E. coli isolates from the LTC applicants were more similar to K. pneumoniae than to E. coli isolates from the employment screening group with regard to a number of characteristics, including (1) a significantly lower diversity of the $b l a_{\text {СтХ-м }}$ genes, (2) a significantly higher frequency of $b l a_{\mathrm{CTX}-\mathrm{M}-15}$ and (3) the occurrence of aminoglycoside resistance genes $a a c\left(6^{\prime}\right)-I b$ and $a n t\left(3^{\prime}\right)-I a$. This assumption is further supported by the lower occurrence of the commensal phylogroup A and the higher occurrence of the pathogenic phylogroup B2 in the E. coli from the LTC applicants and the frequent isolation of the pandemic ST131 clone from this group as well as by differences in the co-resistance patterns. Interestingly, these characteristics of $E$. coli were better explained by origin (i.e. LTC applicantsvs.employmentscreening)thanbyphylogrouping (i.e. commensal vs. pathogenic).

These data, taken together, suggest that ESBL carriage in the community (employment eligibility group) is characterized by different colonization sources. The most obvious source is the exportation of hospital-derived strains either by colonized patients who have been discharged or by hospital workers; such events may be responsible for the introduction of the pathogenic ST131 clone carrying bla $a_{\text {CTX-M-15 }}$ which causes significant morbidity both in hospitals and in the community setting [48]. The source for colonization with isolates carrying bla $_{\mathrm{SHV}}$ may be horizontal gene transfer from exported K. pneumoniae isolates [49-51], while various potential environmental sources should also be considered for $b l a_{\text {СТX-M }}$ genes other than $b l a_{\text {CTХ-M-15 }}$, including food $[52,53]$, companion animals $[54,55]$, wild animals $[56,57]$ surface water $[58]$, drinking water [59] and food [52], either through direct transfer of the resistant bacteria or by the horizontal spread of resistance plasmids to human commensal E. coli.

This assumption is supported by the dominance of $b l a_{\mathrm{CTX}-\mathrm{M}-1}$ among isolates from the work eligibility group and the parallel dominance of $b l a_{\mathrm{CTX}-\mathrm{M}-1}$ in animal-derived Hungarian ESBL-producing $E$. coli isolates [53], in a Polish sample set from water birds [57] and in samples from food and food animals in Switzerland [52] as well as by the high frequency of $b l a_{\mathrm{CTX}-\mathrm{M}-2}$ and $b l a_{\text {СТХ-M-32 }}$ in samples originating in food animals [53, $60]$. These bla genotypes were found exclusively in the individuals screened for work eligibility purposes in this study. The relatedness of animal and human isolates has also been demonstrated in some studies, pointing to a possible zoonotic spread of ESBL-producing E. coli [56, 61].

The presented data underline the complex epidemiology of ESBL producers in the community setting. The ESBL producers or ESBL-encoding genes may reach the human gut microbiota in the community setting via two main routes. Colonization may be the result of the exportation of nosocomial K. pneumoniae or E. coli, characterized by a dominance of $b l a_{\mathrm{CTX}-\mathrm{M}-15}$, multiple co-resistance to other drug types and frequently by clonal spread. The other starting point may be the different environmental sources of mainly commensal $E$. coli characterized by diverse ESBL genes and a high diversity of genotypes of carrier bacteria as well as by a low rate of co-resistance. Though the extent of contribution to human infection by the latter group has still to be established, the increasing prevalence demonstrated by several authors $[6,62]$ is definitely cause for alarm.

\section{Acknowledgements}

G. Kardos was supported by the scholarship TÁMOP 4.2.4. A/2-11-1-2012-0001 'National Excellence Program: Elaborating and operating an inland student and researcher personal support system'. The project was subsidized by the European Union and co-financed by the European Social Fund.
References
1 Damjanova I, Tóth A, Pászti J, Hajbel-Véko- ny G, Jakab M, Berta J, Milch H, Füzi M: Ex- pansion and countrywide dissemination of ST11,ST15 and ST147 ciprofloxacin-resistant CTX-M-15-type beta-lactamase-producing Klebsiella pneumoniae epidemic clones in Hungary in 2005 - the new 'MRSAs'? J Anti- microb Chemother 2008;62:978-985.
2 Woodford N, Ward ME, Kaufmann ME, Tur- ton J, Fagan EJ, James D, Johnson AP, Pike R, Warner M, Cheasty T, Pearson A, Harry S, Leach JB, Loughrey A, Lowes JA, Warren RE, Livermore DM: Community and hospital spread of Escherichia coli producing CTX-M extended-spectrum beta-lactamases in the UK. J Antimicrob Chemother 2004;54:735-743. 
3 Cantón R, Coque TM: The CTX-M beta-lactamase pandemic. Curr Opin Microbiol 2006; 9:466-475.

4 Livermore DM, Canton R, Gniadkowski M, Nordmann P, Rossolini GM, Arlet G, Ayala J, Coque TM, Kern-Zdanowicz I, Luzzaro F, Poirel L, Woodford N: CTX-M: changing the face of ESBLs in Europe. J Antimicrob Chemother 2007;59:165-174.

5 Ewers C, Grobbel M, Stamm I, Kopp PA, Diehl I, Semmler T, Fruth A, Beutlich J, Guerra B, Wieler LH, Guenther S: Emergence of human pandemic O25:H4-ST131 CTX-M-15 extended-spectrum-beta-lactamase-producing Escherichia coli among companion animals. J Antimicrob Chemother 2010;65:651660.

6 Woerther PL, Burdet C, Chachaty E, Andremont A: Trends in human fecal carriage of extended-spectrum beta-lactamases in the community: toward the globalization of CTXM. Clin Microbiol Rev 2013;26:744-758.

7 Salyers AA, Gupta A, Wang Y: Human intestinal bacteria as reservoirs for antibiotic resistance genes. Trends Microbial 2004;12:412416.

8 Tham J, Odenholt I, Walder M, Brolund A, Ahl J, Melander E: Extended-spectrum betalactamase-producing Escherichia coli in patients with travellers' diarrhoea. Scand J Infect Dis 2010;42:275-280.

9 Van der Bij AK, Pitout JD: The role of international travel in the worldwide spread of multiresistant Enterobacteriaceae. J Antimicrob Chemother 2012;67:2090-2100.

10 Heininger A, Binder M, Schmidt S, Unertl K, Botzenhart K, Döring G: PCR and blood culture for detection of Escherichia coli bacteremia in rats. J Clin Microbiol 1999;37:24792482.

11 Liu Y, Liu C, Zheng W, Zhang X, Yu J, Gao Q, Hou Y, Huang X: PCR detection of Klebsiella pneumoniae in infant formula based on $16 \mathrm{~S}$ $23 \mathrm{~S}$ internal transcribed spacer. Int J Food Microbiol 2008;125:230-235.

12 Versalovic J, Koeuth T, Lupski JR: Distribution of repetitive DNA sequences in eubacteria and application to fingerprinting of bacterial genomes. Nucleic Acid Res 1991;19: 6823-6831.

13 Mózes J, Szűcs I, Molnár D, Jakab P, Fatemeh E, Szilasi M, Majoros L, Orosi P, Kardos G: A potential role of aminoglycoside resistance in endemic occurrence of Pseudomonas aeruginosa strains in lower airways of mechanically ventilated patients. Diagn Microbiol Infect Dis 2014;78:79-84.

14 Hunter PR, Gaston MA: Numerical index of the discriminatory ability of typing systems: an application of Simpson's index of diversity. J Clin Microbiol 1998;26:2465-2466.

15 Bedenić B, Randegger CC, Stobberingh E, Hächler H: Molecular epidemiology of extended-spectrum beta-lactamases from Klebsiella pneumoniae strains isolated in Zagreb, Croatia. Eur J Clin Microbiol Infect Dis 2001; 20:505-508
16 Edelstein M, Pimkin M, Palagin I, Edelstein I, Stratchounski L: Prevalence and molecular epidemiology of CTX-M extended-spectrum beta-lactamase-producing Escherichia coli and Klebsiella pneumoniae in Russian hospitals. Antimicrob Agents Chemother 2003;47: 3724-3732.

17 Jouini A, Vinué L, Slama KB, Sáenz Y, Klibi $\mathrm{N}$, Hammami S, Boudabous A, Torres C: Characterization of CTX-M and SHV extended-spectrum beta-lactamases and associated resistance genes in Escherichia coli strains of food samples in Tunisia. Antimicrob Agents Chemother 2007;60:1137-1141.

18 Pitout JD, Hossain A, Hanson ND: Phenotypic and molecular detection of CTX-M-betalactamases produced by Escherichia coli and Klebsiella spp. J Clin Microbiol 2004;42: 5715-5721.

19 Hannecart-Pokorni E, Depuydt F, De Wit L, van Bossuyt E, Content J, Vanhoof R: Characterization of the \pm 9 - $\mathrm{N}$-aminoglycoside acetyltransferase gene $a a c\left(6^{\prime}\right)$-Im associated with a sulI-type integron. Antimicrob Agents Chemother 1997;41:314-318.

20 Noppe-Leclercq I, Wallet F, Haentjens S, Courcol R, Simonet M: PCR detection of aminoglycoside resistance genes: a rapid molecular typing method for Acinetobacter baumannii. Res Microbiol 1999;150:317-322.

21 Frana TS, Carlson SA, Griffith RW: Relative distribution and conservation of genes encoding aminoglycoside-modifying enzymes in Salmonella enterica serotype Typhimurium phage type DT104. Appl Environ Microbiol 2001;67:445-448.

22 Bogaerts P, Galimand M, Bauraing C, Deplano A, Vanhoof R, De Mendonca R, Rodriguez-Villalobos H, Struelens M, Glupczynski Y: Emergence of ArmA and RmtB aminoglycoside resistance 16S rRNA methylases in Belgium. J Antimicrob Chemother 2007;59:459464.

23 Mazel D, Dychinco B, Webb VA, Davies J: Antibiotic resistance in the ECOR collection: integrons and identification of a novel aad gene. Antimicrob Agents Chemother 2000; 44:1568-1574.

24 White DG, Zhao S, Sudler R, Ayers S, Friedman S, Chen S, McDermott PF, McDermott $S$, Wagner DD, Meng J: The isolation of antibiotic-resistant Salmonella from retail ground meats. N Engl J Med 2001;345:1147-1154.

25 Clermont O, Bonacorsi S, Bingen E: Rapid and simple determination of the Escherichia coli phylogenetic group. Appl Environ Microbiol 2000;66:4555-4558.

26 Clermont O, Dhanji H, Upton M, Gibreel T, Fox A, Boyd D, Mulvey MR, Nordmann P, Ruppé E, Sarthou JL, Frank T, Vimont S, Arlet G, Branger C, Woodford N, Denamur E: Rapid and simple detection of the O25b-ST131 clone of Escherichia coli encompassing the CTXM-15 producing strains. J Antimicrob Chemother 2009;64:274-277.

27 Persson S, Olsen KE, Scheutz F, Krogfelt KA, Gerner-Smidt P: A method for fast and simple detection of major diarrhoeagenic Escherichia coli in the routine diagnostic laboratory. Clin Microbiol Infect 2007;13:516-524.

28 Braun G, Vidotto MC: Evaluation of adherence, hemagglutination, and presence of genes codifying for virulence factors of Acinetobacter baumannii causing urinary tract infection. Mem Inst Oswaldo Cruz 2004;99: 839-844.

29 Hammer Q, Harper DAT, Ryan PD: PAST: paleontological statistics software package for education and data analysis, v1.34 (March 17, 2005).

30 De Champs C, Sauvant MP, Chanal C, Sirot D, Gazuy N, Malhuret R, Baguet JC, Sirot J: Prospective survey of colonization and infection caused by expanded-spectrum-beta-lactamase-producing members of the family Enterobacteriaceae in an intensive care unit. J Clin Microbiol 1989;27:2887-2890.

31 Franiczek R, Sobieszczanska B, Grabowski M, Mowszet K, Pytrus T: Occurrence of extended-spectrum beta-lactamases among Escherichia coli isolates from hospitalized and healthy children. Folia Microbiol (Praha) 2003;48:243-247

32 Rodrigues C, Shukla U, Jog S, Mehta A: Extended-spectrum beta-lactamase-producing flora in healthy persons. Emerg Infect Dis 2005;6:981-982.

33 Abdul Rahman EM, El-Sherif RH: High rates of intestinal colonization with extended-spectrum lactamase-producing Enterobacteriaceae among healthy individuals. J Investig Med 2011;59:1284-1286.

34 Luvsansharav UO, Hirai I, Nakata A, Imura K, Yamauchi K, Niki M, Komalamisra C, Kusolsuk T, Yamamoto Y: Prevalence of and risk factors associated with faecal carriage of CTX$\mathrm{M}$ beta-lactamase producing Enterobacteriaceae in rural Thai communities. J Antimicrob Chemother 2012;67:1769-1774.

35 Peirano G, Laupland KB, Gregson DB, Pitout JD: Colonization of returning travelers with CTX-M-producing Escherichia coli. J Travel Med 2011;18:299-303.

36 Tangden T, Cars O, Melhus A, Lowdin E: Foreign travel is a major risk factor for colonization with Escherichia coli producing CTXMtype extended-spectrum beta-lactamases: a prospective study with Swedish volunteers. Antimicrob Agents Chemother 2010;54: 3564-3568

37 Coque TM, Baquero F, Canton R: Increasing prevalence of ESBL-producing Enterobacteriaceae in Europe. Euro Surveill 2008; 13 : 19044.

38 Nicolas-Chanoine MH, Gruson C, BialekDavenet S, Bertrand X, Thomas-Jean F, Bert F, Moyat M, Meiller E, Marcon E, Danchin $\mathrm{N}$, Noussair L, Moreau R, Leflon-Guibout $\mathrm{V}$ : 10-fold increase (2006-2011) in the rate of healthy subjects with extended-spectrum beta-lactamase producing Escherichia coli faecal carriage in a Parisian check-up centre. J Antimicrob Chemother 2013;68:562568. 
39 Stromdahl H, Tham J, Melander E, Walder M, Edquist PJ, Odenholt I: Prevalence of faecal ESBL carriage in the community and in a hospital setting in a county of Southern Sweden. Eur J Clin Microbiol Infect Dis 2011;30:11591162.

40 Geser N, Stephan R, Korczak BM, Beutin L, Hachler H: Molecular identification of extended-spectrum-beta-lactamase genes from Enterobacteriaceae isolated from healthy human carriers in Switzerland. Antimicrob Agents Chemother 2012;56:1609-1612.

41 Rodriguez-Bano J, Lopez-Cerero L, Navarro MD, Diaz de Alba P, Pascual A: Faecal carriage of extended-spectrum beta-lactamase producing Escherichia coli: prevalence, risk factors and molecular epidemiology. J Antimicrob Chemother 2008;62:1142-1149.

42 Schoevaerdts D, Verroken A, Huang TD, Frennet M, Berhin C, Jamart J, Bogaerts P, Swine C, Glupczynski Y: Multidrug-resistant bacteria colonization amongst patients newly admitted to a geriatric unit: a prospective cohort study. J Infect 2012;65:109-118.

43 Tofteland S, Haldorsen B, Dahl KH, Simonsen GS, Steinbakk M, Walsh TR, Sundsfjord A; Norwegian ESBL Study Group: Effects of phenotype and genotype on methods for detection of extended-spectrum-beta-lactamase-producing clinical isolates of Escherichia coli and Klebsiella pneumoniae in Norway. J Clin Microbiol 2007;45:199-205.

44 Pitout JD, Hanson ND, Church DL, Laupland KB: Population-based laboratory surveillance for Escherichia coli-producing extendedspectrum beta-lactamases: importance of community isolates with blaCTX-M genes. Clin Infect Dis 2004;38:1736-1741.

45 Hansen DS, Schumacher H, Hansen F, Stegger M, Hertz FB, Schønning K, Justesen US, Frimodt-Møller N; DANRES Study Group: Extended-spectrum beta-lactamase (ESBL) in Danish clinical isolates of Escherichia coli and Klebsiella pneumoniae: prevalence, betalactamase distribution, phylogroups, and coresistance. Scand J Infect Dis 2012;44:174181.

46 Tsukamoto N, Ohkoshi Y, Okubo T, Sato T, Kuwahara O, Fujii N, Tamura Y, Yokota S: High prevalence of cross-resistance to aminoglycosides in fluoroquinolone-resistant Escherichia coli clinical isolates. Chemotherapy 2013;59:379-384.
47 Skurnik D, Le Menac'h A, Zurakowski D, Mazel D, Courvalin P, Denamur E, Andremont A, Ruimy R: Integron-associated antibiotic resistance and phylogenetic grouping of Escherichia coli isolates from healthy subjects free of recent antibiotic exposure. Antimicrob Agents Chemother 2005;49:3062-3065.

48 Lau SH, Kaufmann ME, Livermore DM, Woodford N, Willshaw GA, Cheasty T, Stamper K, Reddy S, Cheesbrough J, Bolton FJ, Fox AJ, Upton M: UK epidemic Escherichia coli strains A-E, with CTX-M-15 beta-lactamase, all belong to the international O25:H4-ST131 clone. J Antimicrob Chemother 2008;62:1241-1244.

49 Coque TM, Oliver A, Pérez-Díaz JC, Baquero F, Cantón R: Genes encoding TEM-4, SHV-2, and CTX-M-10 extended-spectrum beta-lactamases are carried by multiple Klebsiella pneumoniae clones in a single hospital (Madrid, 1989-2000). Antimicrob Agents Chemother 2002;46:500-510.

50 Tellevik MG, Sollid JE, Blomberg B, Jureen R, Urassa WK, Langeland N: Extended-spectrum beta-lactamase-type SHV-12-producing Enterobacteriaceae causing septicemia in Tanzanian children: vectors for horizontal transfer of antimicrobial resistance. Diagn Microbiol Infect Dis 2007;59:351-354.

51 Doi Y, Adams-Haduch JM, Peleg AY, D’Agata EM: The role of horizontal gene transfer in the dissemination of extended-spectrum beta-lactamase-producing Escherichia coli and Klebsiella pneumoniae isolates in an endemic setting. Diagn Microbiol Infect Dis 2012;74:34-38.

52 Geser N, Stephan R, Hächler H: Occurrence and characteristics of extended-spectrum beta-lactamase (ESBL) producing Enterobacteriaceae in food producing animals, minced meat and raw milk. BMC Vet Res 2012;8:21.

53 Tóth A, Juhász-Kaszanyitzky É, Mag T, Hajbel-Vékony G, Pászti J, Damjanova I: Characterization of extended-spectrum beta-lactamase (ESBL) producing Escherichia coli strains isolated from animal and human clinical samples in Hungary in 2006-2007. Acta Microbiol Immunol Hung 2013;60:175-185.

54 Carattoli A, Lovari S, Franco A, Cordaro G, Di Matteo P, Battisti A: Extended-spectrum beta-lactamases in Escherichia coli isolated from dogs and cats in Rome, Italy, from 2001 to 2003. Antimicrob Agents Chemother 2005; 49:833-835.
55 Wieler LH, Ewers C, Guenther S, Walther B, Lübke-Becker A: Methicillin-resistant staphylococci (MRS) and extended-spectrum betalactamases (ESBL)-producing Enterobacteriaceae in companion animals: nosocomial infections as one reason for the rising prevalence of these potential zoonotic pathogens in clinical samples. Int J Med Microbiol 2011;301: 635-641.

56 Bonnedahl J, Drobni M, Gauthier-Clerc M, Hernandez J, Granholm S, Kayser Y, Melhus A, Kahlmeter G, Waldenström J, Johansson A, Olsen B: Dissemination of Escherichia coli with CTX-M type ESBL between humans and yellow-legged gulls in the south of France. PLoS One 2009;4:e5958.

57 Literak I, Dolejska M, Janoszowska D, Hrusakova J, Meissner W, Rzyska H, Bzoma S, Cizek A: Antibiotic-resistant Escherichia coli bacteria, including strains with genes encoding the extended-spectrum beta-lactamase and QnrS, in waterbirds on the Baltic Sea coast of Poland. Appl Environ Microbiol 2010;76:8126-8134.

58 Tacão M, Moura A, Correia A, Henriques I: Co-resistance to different classes of antibiotics among ESBL-producers from aquatic systems. Water Res 2014;48:100-107.

59 De Boeck H, Miwanda B, Lunguya-Metila O, Muyembe-Tamfum JJ, Stobberingh E, Glupczynski Y, Jacobs J: ESBL-positive Enterobacteria isolates in drinking water. Emerg Infect Dis 2012;18:1019-1020.

60 Bortolaia V, Larsen J, Damborg P, Guardabassi L: Potential pathogenicity and host range of extended-spectrum beta-lactamaseproducing Escherichia coli isolates from healthy poultry. Appl Environ Microbiol 2011;77:5830-5833.

61 Overdevest I, Willemsen I, Rijnsburger M, Eustace A, Xu L, Hawkey P, Heck M, Savelkoul $\mathrm{P}$, Vandenbroucke-Grauls C, van der Zwaluw K, Huijsdens X, Kluytmans J: Extended-spectrum beta-lactamase genes of Escherichia coli in chicken meat and humans, The Netherlands. Emerg Infect Dis 2011;17:1216-1222.

62 Valverde A, Coque TM, Sánchez-Moreno MP, Rollán A, Baquero F, Cantón R: Dramatic increase in prevalence of fecal carriage of extended-spectrum beta-lactamase-producing Enterobacteriaceae during non-outbreak situations in Spain. J Clin Microbiol 2004;42: 4769-4775.
ESBL Carriage in Asymptomatic

Individuals
Chemotherapy

DOI: $10.1159 / 000375407$ 